
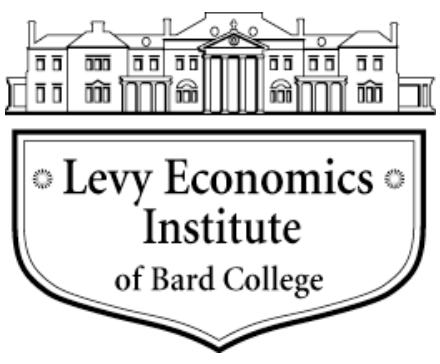

Working Paper No. 803

\title{
What Do We Know About the Labor Share and the Profit Share? Part I: Theories
}

by

\author{
Olivier Giovannoni* \\ Levy Economics Institute of Bard College
}

May 2014

* Correspondence: ogiovann@bard.edu. Translation assistance was provided by Dam Linh Nguyen, while Lei Lu provided research assistance for the technology section. Both Linh and Lei acknowledge financial assistance from the Bard Summer Research Institute. All remaining errors remain the author's sole responsibility.

The Levy Economics Institute Working Paper Collection presents research in progress by Levy Institute scholars and conference participants. The purpose of the series is to disseminate ideas to and elicit comments from academics and professionals.

Levy Economics Institute of Bard College, founded in 1986, is a nonprofit, nonpartisan, independently funded research organization devoted to public service. Through scholarship and economic research it generates viable, effective public policy responses to important economic problems that profoundly affect the quality of life in the United States and abroad.

Levy Economics Institute

P.O. Box 5000

Annandale-on-Hudson, NY 12504-5000

http://www.levyinstitute.org

Copyright (C) Levy Economics Institute 2014 All rights reserved

ISSN 1547-366X 


\begin{abstract}
This series of working papers explores a theme enjoying a tremendous resurgence: the functional distribution of income - the division of aggregate income by factor share. This first installment surveys some landmark theories of income distribution. Some provide a technology-based account of the relative shares while others provide a demand-driven explanation (Keynes, Kalecki, Kaldor, Goodwin). Two questions lead to a better understanding of the literature: is income distribution assumed constant?, and is income distribution endogenous or exogenous? However, and despite their insights, these theories alone fail to fully explain the current deterioration of income distribution.
\end{abstract}

Subsequent installments are dedicated to analyzing the empirical literature (part II), to the measurement and composition of the relative shares (part III), and to a study of the role of economic policy (part IV).

Keywords: Wage Share; Labor Share; Profit Share; Ergodicity; Technology JEL Classifications: D33, E24, E25 


\section{CONTENTS}

1 INTRODUCTION: HOW BIG OF A SLICE DOES THE PIE-MAKER GET? ........... 3

2 KEYNES: HINTS, CONCERNS, BUT NO THEORY …….................................................. 7

3 THE INCOME DISTRIBUTION POLITICAL ECONOMY OF MICHAL KALECKI 10

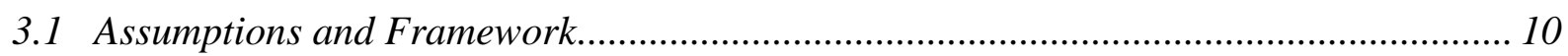

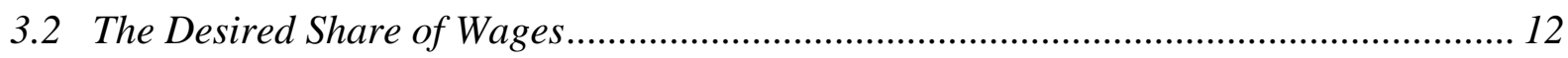

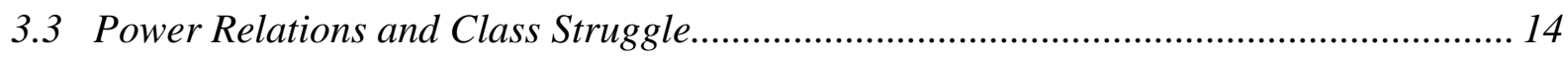

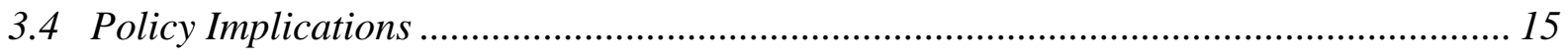

4 KALDOR AND PASINETTI: INCOME DISTRIBUTION FOR FULL

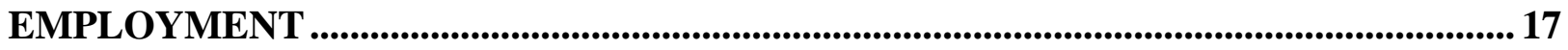

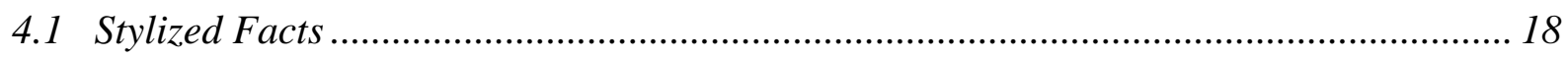

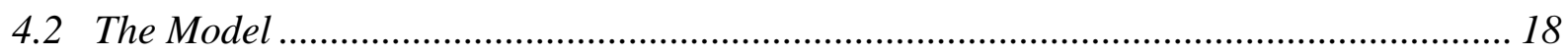

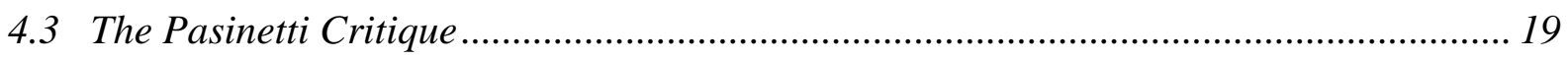

4.4 Full Employment vs. Harrodian Dynamics .................................................................. 21

4.5 A Full Employment Keynesian Model................................................................... 22

\section{THE INCOME DISTRIBUTION BUSINESS CYCLE MODEL OF RICHARD}

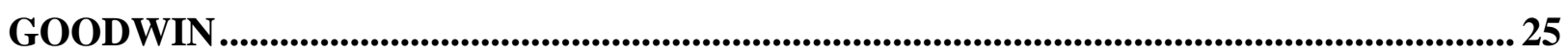

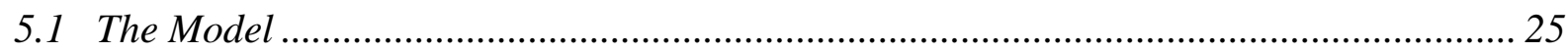

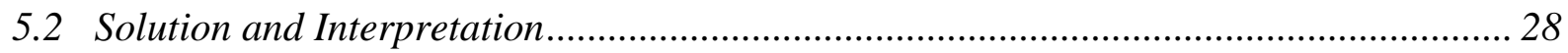

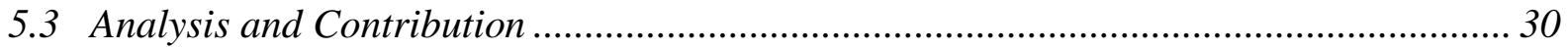

6 TECHNOLOGY AND THE SHAPE OF THE PRODUCTION FUNCTION .............. 32

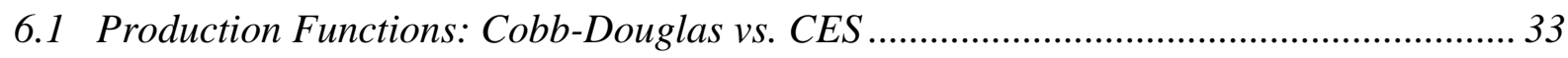

6.2 Technical Change in the CES Production Function.................................................... 37

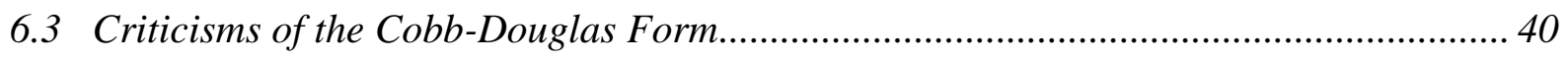

7 WHAT HAVE WE LEARNED? (NON)ERGODICITY AND THE ROLE OF ECONOMIC POLICY ....................................................................................................................... 44

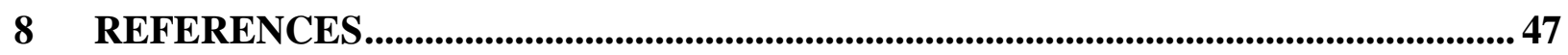




\section{INTRODUCTION: HOW BIG OF A SLICE DOES THE PIE-MAKER GET?}

Of the tendencies that are harmful to sound economics, the most seductive, and in my opinion the most poisonous, is to focus on questions of distribution. [...] But of the vast increase in the well-being of hundreds of millions of people that has occurred in the 200-year course of the industrial revolution to date, virtually none of it can be attributed to the direct redistribution of resources from rich to poor. The potential for improving the lives of poor people by finding different ways of distributing current production is nothing compared to the apparently limitless potential of increasing production.

This paper addresses the functional distribution of income, i.e., it discusses the size of the slice of the economic pie going to each factor of production, as a reward. As the aggregate shares in output are considered, the functional distribution of income is deeply rooted in macroeconomic analysis. The functional distribution of income is not to be confused with the personal distribution of income, which studies the distribution of income across individuals, or households, and which has traditionally received a microeconomic treatment. ${ }^{2}$ However, it would be a mistake to pitch both distributions against each other or to believe that they have nothing in common. As will be shown, the same underlying forces may be shaping both the functional and the personal income distributions, in the same way that there can be two related symptoms of the same disease.

The issue of income distribution is both old and new. On one hand, income distribution is the oldest question in economics: How much of the economic pie does each factor, and therefore social class, receive? Ricardo (1817) famously opens his magnum opus by elevating the question to the principal problem of political economy:

\footnotetext{
${ }^{2}$ The work of James K. Galbraith on the macroeconomic dimension of inequality is a rare and welcome exception.
} 
The produce of the earth - all that is derived from its surface by the united application of labour, machinery and capital, is divided among three classes of the community, namely, the proprietor of the land, the owner of the stock or capital necessary for its cultivation, and the labourers by whose industry it is cultivated. But in different stages of society, the proportions of the whole produce of the earth which will be allotted to each of these classes, under the names of rent, profit, and wages, will be essentially different [...] To determine the laws which regulate this distribution is the principal problem in Political Economy [...]

- David Ricardo (1817), p. 1

Besides Ricardo, economists have treated the topic in a way that can only be described as bipolar (Solow, 1958). Going down history lane, the times of manic interest were under the Physiocrats and classical economists (including, of course, Marx), the early 20th century and its first statistical inquiries, as well as the 1950s and 60s. The depressive phases fill the gaps. The topic fell notably into oblivion during the marginalists' times as well as in the 30s, 40s, 70s and 80s. In the 1990s interest in income distribution grew, albeit for its most visible manifestation at the time, the personal type (inequality). The 2000s saw a marked deterioration of the functional distribution, in the U.S. and worldwide, and with it, an increase in the research devoted to understanding the underlying causes. The topic has gained enormous traction since the mid-2000s, an interest reinforced by the global crisis of 2008 and the greater availability of distribution statistics (Giovannoni, 2013b).

A reason for the distribution of income to fall into oblivion may be that relative shares have been fairly constant over long periods of time (Giovannoni, 2013c), so much so that the relative constancy of the factor shares came to be considered alternatively a "bit of a miracle" (Keynes 1939), a "stylized fact" (Kaldor 1961) or even a law (“Bowley's law”). ${ }^{3}$ Long ago, Keynes noticed that the stability of the labor share, over a fifty-five year period, is

A well-known statistical phenomenon [which] confirms the probability of constant or diminishing, rather than increasing, profit per unit of output when output increases. I mean the stability of the proportion of the national dividend accruing to labour, irrespective apparently of the level of output as a whole and of the phase of the trade cycle. This is one of the most

\footnotetext{
${ }^{3}$ A term coined by Samuelson (1964a) referring to the works on aggregate wages and national income of the British statistician Arthur Bowley (1969-1957). See Bowley (1900, 1920, 1937)
} 
surprising, yet best-established, facts in the whole range of economic statistics both for Great Britain and for the United States [...] It is the stability of the ratio for each country which is chiefly remarkable, and this appears to be a long-run, and not merely a short-period, phenomenon. [...]

- John Maynard Keynes (1939), pp.48-9

But the labor share cannot reasonably be considered constant anymore. The actual stability of the distribution of income came to be put into question starting in the 1970s. Real wages and labor productivity became disconnected, leading the US labor share to track downward around that time. The trend became clearly visible in the 1980s (see Fig. 1). The good economy and low unemployment of the late 1990s did produce an increase as expected, ${ }^{4}$ but it was unable to invert the trend. The major recession of 2008 barely produced an uptick. In the 2000s, the trend won, and the labor share has been decidedly falling, posing a serious puzzle to economists since then. It is this puzzle, the reasons why the labor share has been falling while it used to be constant, that this paper aims to elucidate. Just what is known about the labor and profit shares?

In this first of a four-part series, some theories devised during the "years of high theory" are investigated. The present paper highlights a few contributions characteristic of those years. This paper does not claim any exhaustive account. Rather, it is better understood as consisting of a series of lightposts, casting light at distant intervals, in such a way that a general direction emerges but many areas remain in the darkness. To cast light onto those areas, the reader is directed to the subsequent installments of this first theoretical part addressing, in turn, the empirical evidence of the determinants of the labor share (part II), the labor share measures and structural features (part III) and economic policies (part IV).

\footnotetext{
${ }^{4}$ The labor share is procyclical; see Giovannoni (2013c) for more details.

${ }^{5}$ The sentence harks back to the special issue of the Cahiers d'Économie Politique (Papers in Political Economy) entitled "What have we learned on income distribution since the "years of high theory'?", number 61. We here extend the "years of high theory" from the 1920s to the 1970s.
} 
Figure 1 Labor Share of GDP in the U.S. Nonfarm Business Sector

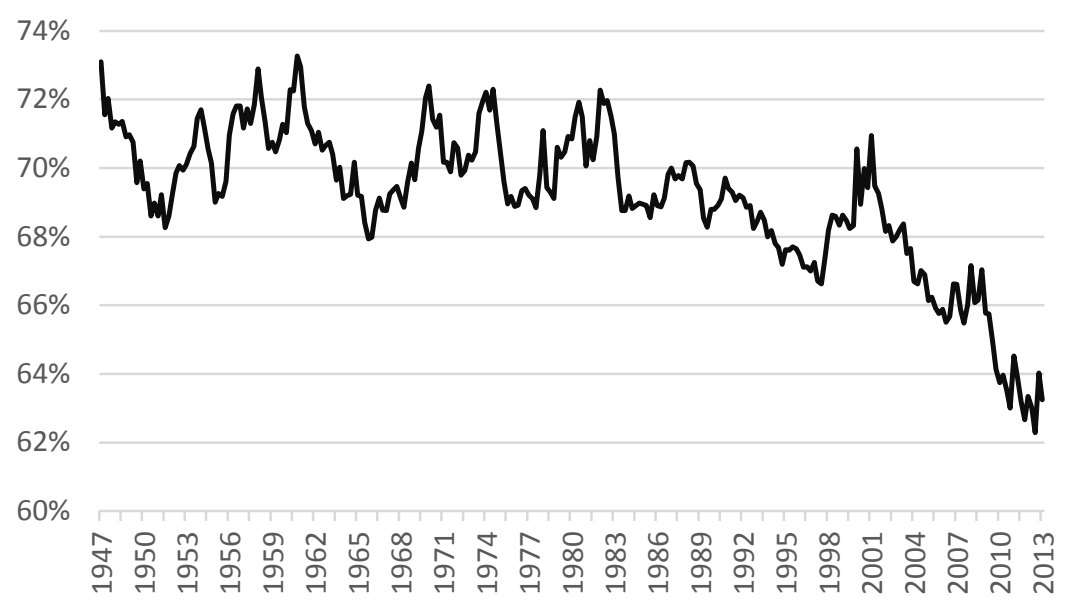

Source: BLS, productivity and costs tables

The present paper is roughly organized in a chronological way in order to highlight the progression (or, the differences, departures) in economic thought. In turn, it will show the hints left by Keynes (section 2) as well as the contributions of Kalecki, Kaldor and Pasinetti and Goodwin (sections 3, 4 and 5, respectively). Section 6 describes the role of technology and the related assumptions regarding production functions, while section 7 presents some concluding remarks in the form of finding a common thread among those theories. 


\section{KEYNES: HINTS, CONCERNS, BUT NO THEORY}

[...] there is evidence that in its early stages, Keynes' own thinking tended to develop in this direction [to study income distribution] -only to be diverted from it with the discovery (made some time between the publication of the Treatise on Money and the General Theory) that inflationary and deflationary tendencies could best be analysed in terms of the resulting changes in output and employment, rather than in their effects on prices.

- Nicolas Kaldor (1956), p. 83

Keynes' theory of income distribution can be assessed through his two most important works, the Treatise on Money and The General Theory of Employment, Interest and Money. The term "distribution" is cited thirty-two times in the General Theory, but no book, chapter, or section title includes the word "distribution" - there is not even a "distribution" entry in the index. This count indicates a certain interest but is scarcely an indication of a main theme. The reason for this relative absence is that the purpose of these two books is not the study of income distribution; in those works Keynes talks respectively about money and aggregate demand, that is, what it takes to generate employment and income, not how the income is distributed once created (see Kaldor's quote).

For Davidson (1960), Keynes discusses income distribution as soon as 1930 in the famous parable of the widow's cruse:

If entrepreneurs choose to spend a portion of their profits on consumption [...] the effect is to increase the profit on the sale of liquid consumption goods by an amount exactly equal to the amount of profits which have been thus expended [...] Thus, however, much of profits entrepreneurs spend on consumption, the increment of wealth belonging to the entrepreneurs remains the same as before. Thus, profits, as a source of capital increment for entrepreneurs, are a widow's cruse which remains undepleted, however much of them may be devoted to riotous living. When, on the other hand, entrepreneurs are making losses, and seek to recoup these losses by curtailing their normal expenditures on consumption i.e., by saving more, the cruse becomes the Danaid jar which can never be filled-up; the effect of this reduced expenditure is to inflict on the producers of consumption-goods a loss of an equal amount. Thus the diminution of their wealth as a class, is as great, in spite of their saving, as it was before.

- John Maynard Keynes (1930), p. 139 
Through this metaphor, Keynes specifies that the more capitalists spend, the greater the total amount of profits they receive. Conversely, entrepreneurs' spending cuts necessarily mean a lower overall profit level. Profits thus appear as a special category of income in the sense that they must be spent to generate more income (and new profits). If there is no profit and/or if capitalists do not spend, production and employment will stagnate. This reasoning is also attributed to Kalecki (by Joan Robinson), as the adage "capitalists earn what they spend and employees spend what they earn." Keynes thus isolates a very special variable in the functioning of the economy: profits. The widow's cruse parable tells us about the thinking of Keynes c.1930: the question of the functional distribution of income between wages and profits is not far-but a question Keynes discusses only "in passing." In 1930, Keynes preferred to treat the determinants and the level of income (both sector consumption / production), but does not compare to the aggregate level of income.

These observations give Keynes a special place among the theories of income distribution - for in Keynes there is no distribution theory per se, just hints at one. The father of macroeconomics and master of economic aggregates knows that income distribution matters but his purpose is elsewhere. ${ }^{6}$ Keynes does not develop a theory of income distribution, and the marginalists' approach appears unchallenged, simple, and intellectually appealing (see section 6 esp. the Euler Theorem).

Keynes came really close to an analysis of income distribution in the General Theory. Indeed his major work is centered on three specific real variables: wages, employment, and output. Those alone define the share of labor:

$$
\frac{W}{Y}=\frac{w N}{Y}
$$

where $W$ is the wage bill, $w$ is the nominal wage, the level of employment $N$, and $Y$ the level of production (or value added). After painfully precise definitions and analysis of each of those three variables we expect Keynes to add a "synthesis" section addressing income

\footnotetext{
${ }^{6}$ Keynes had plans to develop his "real economy" analysis, following developments the monetary Treatise on Money. It is sometimes said that Keynes hesitated to embark on a theory of income distribution in the early thirties, but after the article by Richard Kahn (1931), Keynes preferred the revision and integration of his earlier ideas on uncertainty (Treatise on Probability), on currency (the Treatise on Money) and a demand analysis. The result is the General Theory. See

Kahn, R. (1931) The Relation of Home Investment to Unemployment, The Economic Journal, 41, 162, 173-198.

Kahn, R. (1933) The Elasticity of Substitution and the Relative Share of a Factor, The Review of Economic Studies, $1,1,72-78$.
} 
distribution. $^{7}$ But Keynes only shares, as a conclusion, a concern with income distribution: that the "inequitable distribution of wealth and incomes" was an outstanding failure of the capitalist economy. The book ends there. Overall, the introductory paragraphs to chapter 18 might best expose Keynes' thought:

We take as given [...] the degree of competition [...] as well as the social structure including the forces [...] which determine the distribution of the national income. This does not mean that we assume these factors to be constant; but merely that, in this place and context, we are not considering or taking into account the effects and consequences of changes in them.

- John Maynard Keynes (1936), p.245

\footnotetext{
${ }^{7}$ Keynes treated equally brief personal distribution of wealth and income (i.e, of the income inequality) in the conclusion in terms of social philosophy of the General Theory.
} 


\section{THE INCOME DISTRIBUTION POLITICAL ECONOMY OF MICHAL KALECKI}

At the same time that Keynes wrote his magnum opus, Michal Kalecki started a series of working papers specifically on income distribution. Kalecki refined his views in a series of articles and books (Kalecki 1935, 1938, 1942, 1954, 1962). For Kalecki, income distribution is inherently related to the ability of "capitalists" to pass wage increases on to prices. Thus income distribution is primarily a matter of degree of imperfect competition and, within it, the balance of power between actors. Income distribution, market structure and pricing are interrelated and explain economic growth and the business cycle. Among the different vintages of Kalecki's theory we will present the latest (1954) and most preferred by Kalecki himself.

\subsection{Assumptions and Framework}

Kalecki's model is best understood when exposed "from the ground up," i.e., starting from its assumptions; there are five primary ones. Note that not all assumptions are relevant to Kalecki's theory of income distribution; for that purpose, only 1, 2 and 4 are necessary. Assumptions 3 and 5 set the broader framework.

1. There are two antagonistic classes: "capitalists" and "workers."

2. Imperfect (oligopolistic) competition is the norm. Each firm is facing a

downward-sloping demand curve, meaning that each firm is demand-constrained. This is in contrast to perfect competition where each firm faces an infinitely elastic demand curve, so that demand changes do not affect prices -only costs and prices do (Lopez and Assous, 2010).

3. Information is imperfect. Information (or lack thereof) plays a critical role in investment decisions.

4. Less-than-full employment. As a result of 2 and 3, the economy is considered in a situation of chronic underemployment of the factors of production, i.e. excess capacity prevails.

5. The economy is a monetary economy in the sense that credit plays an important role. "Capitalists" and the State can finance their spending by borrowing from banks. 
A note on the method seems necessary as well, for two things single out Kalecki's theory among heterodox economists. First, Kalecki does not assume price rigidity. A separate and related theory of prices is developed where prices are endogenous and a function of the degree of monopoly, the same parameter which, we will see, matters for the distribution of income. Second, Kalecki is interested in the macroeconomic picture and especially in the distribution of income in the aggregate, but he takes pains to derive a model that is micro-founded.

Now that the framework is set we can derive Kalecki's profit equation. The latter stems from the two national accounting identities defining output, one from the spending and one from the income side. First, assuming away the government and foreign sectors for simplification,

$$
Y \equiv C_{w}+C_{c}+I
$$

where $C_{w}, C_{c}$ represents workers' and capitalists' consumption, respectively. Second, production is the sum of total wages and total profits $(\Pi)$, so that:

$$
Y \equiv W+\Pi
$$

Assuming that all wages are consumed, i.e., $W=C_{w}$, and combining equation (2) and equation (3) we arrive at the definition of profits as

$$
\Pi=C_{c}+I
$$

Equation (4) is an identity so that the direction of causality is unknown. However, Kalecki remarks that if there is a profit, it must be the case that some output was sold in the first place. Thus, there must have been some demand first and causality in (4) must run from expenditure (conveniently put on the RHS) toward profits (voluntarily placed on the LHS). Kalecki finds a result also envisioned in Keynes and confirmed in Kaldor: capitalists earn ( what they spend $\left(I+C_{c}\right)$, while workers spend what they earn $\left(W=C_{w}\right)$. 


\subsection{The Desired Share of Wages}

There are several vintages of Kalecki's theory of income distribution, the most famous of which involves the share of profits as fixed and given (Kalecki 1954). The exogeneity of the profit share is justified by the market structure, and the existence of the capitalist class which has the decision-making power. In this formulation, the share of profits $(\beta)$ that is desired by capitalists is defined as $\beta^{*}$ :

$$
\beta=\beta^{*}
$$

Therefore, the wage share is defined as $\alpha^{*}=1-\beta^{*}$, i.e., it is derived as a residual when the balance of power leans towards capitalists.

The share of profits $\beta=\Pi / Y$ and equation (5) can be used to extract the level of activity such as:

$$
Y^{*}=\frac{1}{\beta^{*}} \Pi
$$

Equation (6) states that the production level depends both on the share and the level of profits. Coefficient $1 / \beta^{*}$ can be called an "income distribution multiplier" (my words, not Kalecki's) and is equal to the inverse of the share of profits desired by capitalists. The level of expenditure that capitalists contribute to profits is given, so that profits are also given. This means that production varies inversely with the share of profits. Capitalists must curtail production in order to increase their profit share. Thus, with constant spending on the capitalists' part, a higher profit share can only be achieved if output and employment are limited.

Profits are defined as the sales proceeds minus total costs. For simplification we define total costs as comprising only of wages and raw materials (or intermediate products). Sales proceeds in turn are defined as prime costs (wages and raw materials) marked up by a factor $k$, that Kalecki calls the degree of monopoly. The degree of monopoly is defined as the price-to-cost ratio in a particular industry. By definition then (see Lopez and Assous, 2010) 


$$
\Pi=(k-1)\left(W+P_{\text {mat }}\right)
$$

where $P_{m a t}$ represents the price of raw materials, i.e. costs other than wages. Using equation (3) and (7) we get an expression for output

$$
Y=W+(k-1)\left(W+P_{\text {mat }}\right)
$$

Dividing through by the wages bill $W$ and taking the inverse we arrive at the wage share $\alpha$.

$$
\alpha=\frac{1}{1+(k-1)(j+1)}
$$

with $j=P_{m a t} / W$. In the particular and simpler case of the absence of raw materials (or if their price is constant) we can rewrite equation (9) as

$$
\alpha=1 / k
$$

This last expression states that the wage share is inversely related to the degree of monopoly. A very competitive market with low degree of monopoly will see a very high wage share whereas an oligopolistic market will see a much lower labor share.

Therefore, the wage share is given by four factors, all interrelated:

1. The intensity of the class struggle, through which capitalists and unions clash;

2. The importance in total value added of imperfectly competitive firms;

3. The degree of monopoly, which the markup "reflects" (Kalecki, 1954);

4. The ratio of aggregate prices to materials prices, $j$.

The first three factors are self-explanatory or are taken from equation (9). Recall also that the wage share arrived at in equation (9) and (10) are wage shares desired by capitalists. Would capitalists always achieve their desired share of profits? Again, this depends on the balance of power in the class struggle. 
In order to see why, we define the wages bill as:

$$
\begin{gathered}
W=Y-\Pi \\
W=\Pi / \beta^{*}-\Pi \\
W=\frac{1-\beta^{*}}{\beta^{*}} \Pi
\end{gathered}
$$

Equation (13) states that the desired income shares are given by the decisions of capitalists' expenditures (reflected in profits). We now have a whole system based on the decisions of capitalists:

1. Capitalists spend;

2. the amount of capitalists' spending implicitly determines

(a) their income, and,

(b) overall income, out of which wages and salaries are paid, once profits have been distributed,

(c) capitalist spending determines (among other things, see above) the distribution of income.

\subsection{Power Relations and Class Struggle}

The evolution of the wage rate is part of a more complex mechanism. Kalecki considers two cases: either an increase in the wage rate leads to a constant share of profits, or capitalists accept a decline in the share of profits.

In the first case, as we have seen, the balance of power lies in capitalists' hands: the increase in the wage rate causes an extra cost of production for capitalists, but capitalists enjoy enough monopoly and bargaining power to pass on the full wage increases on to the price of production. In this case the increase in the nominal wage rate corresponds to a real wage stagnation and workers' purchasing power is unchanged.

The second case is more complex. If capitalists are not powerful enough in relation to unions, then capitalists are not able to pass all wage increases on to prices. This causes two things. On one hand, capitalists' profits remain unchanged since they depend on capitalists' willingness to spend. On the other hand, salary increases lead to a larger wages bill, which mechanically 
increases consumption. As a result, companies are subject to higher demand, at least in the short run, and so capacity utilization rises. The end result is that consumption and investment are at higher levels. This corresponds to a situation with greater production, but with a smaller share of profits. The result: growth comes with a declining share of profits — we have wage-led growth. Kalecki is more interested in this latter case. Under this scenario, there are sufficiently strong unions to counteract capitalists' decisions by increasing consumer demand; hence, giving rise to profits and employment.

\subsection{Policy Implications}

The capitalist class dominates the economic system proposed by Kalecki. This dominance is characterized by a too-high profit share to maintain or generate full employment and economic growth. In that case, the share of profits hinders economic growth and what is needed to restore growth and employment is wage-led growth.

Kalecki discusses an exogenous intervention to avoid such undesirable outcome: the intervention of the state for wage-led growth (Lopez and Assous, 2010). This requires us to generalize the framework presented so far to include a foreign and public sector.

In an open economy with a government sector, the above remains true, with the provision that each variable is defined net of taxes, and we have:

$$
\Pi \equiv C_{c}+I+(G-T)+(X-M)
$$

which means that capitalists are no longer entirely controlling the profit level / share. A higher fiscal deficit and/or trade surplus increases profits, output and employment, but it may come at the expense of capitalists' profit share. Capitalists may want net exports $(X-M)$ to increase, because their production would go up and exports may be a way to beat a competitor. However, positive net exports may lead to a lower profit share, depending on the fiscal balance.

But what fiscal stance would capitalists prefer? As equations (6) and (14) indicate,

- A high fiscal deficit $(G-T)>0$ may increase profits, but this would reduce the profit share further. 
- Any fiscal surplus $(G-T)<0$ may decrease profits but it will increase the profit share. If capitalists' objective is to maintain or even increase their profit share, the fiscal policy of choice is that of relatively low spending and high taxes.

More precisely, Kalecki examines three cases:

- The budget is balanced state expenditure and a tax levied on wages of an equivalent amount. In this case there is a crowding-out effect of consumption by the public expenditure so that the net effect is zero for the entire system. The government spending multiplier is one.

- The budget is balanced by state expenditure and a tax levied on profits of an equivalent amount. If capitalists' spending decisions remain unchanged, then profits before tax are not changed. We are in the case discussed previously with the same conclusions. Capitalists have the option to either pass the tax increase entirely on to wages or on to prices. Kalecki notes that the repercussion is never completely in one direction; mainly because a tax levied on profits results in a decrease in the share of profits. Consequently, the reasoning is the same as it was previously: the decline in the share of profits leads to greater consumption, and thus boosts the economy. This balanced budget multiplier is greater than one.

- Finally, if the budget is in deficit, the effect is twofold: the deficit benefits both capitalists and workers, and both growth and employment go up. The converse is that a fiscal surplus results in a tax levied on aggregate demand so that the surplus is levied on the whole dynamic of the system.

Kalecki's model combines different concepts we have discussed so far, especially some of the ideas of Keynes, whose early ideas Kalecki was not necessarily aware of. The major contribution of Kalecki's model is to propose a tractable framework in the case of under-employment. The immediate conclusion is that in an economy with excess capacity, State intervention is justified. The State can alter power relations between workers and capitalists and it can influence the distribution of income. Whatever the vintage, the distribution of income remains central to the theory of Kalecki. This distribution is defined by exogenous conditions such as state intervention, but this exogeneity does not result in a neutrality of distribution. In all, for Kalecki, a distribution in favor of profits-e.g., due to heightened bargaining power of capitalists over workers - is both the cause and the consequence of lower economic performance. 


\section{KALDOR AND PASINETTI: INCOME DISTRIBUTION FOR FULL EMPLOYMENT}

[...] no hypothesis as regards the forces determining distributive shares could be intellectually satisfying unless it succeeds in accounting for the relative stability of these shares in the advanced capitalist economies over the last 100 years or so, despite the phenomenal changes in the techniques of production, in the accumulation of capital relative to labor and in real income per head.

- Nicholas Kaldor (1956), p.84

The Post-WWII the economics profession became very interested in the issue of economic growth. The Keynesian proposition that had been holding for two decades is that economic growth depends on effective aggregate demand. Heterodox economists, following Keynes (1936) and Harrod (1939), insisted on investment while neoclassical economists insisted on the role of savings and technological progress (Solow, 1956). But how were saving and investment related to economic growth?

Kaldor $(1956,1957)$ finds that income distribution matters to the correlation of savings with economic growth. This comes in contrast to the Solow (1956) growth model, for instance, where income distribution does not matter for economic growth (Bertoli and Farina, 2007). ${ }^{8}$ Further, Kaldor demonstrates that, assuming heterogeneous saving rates for workers and capital owners, workers' savings rate does not matter much at all for income distribution. Only investment and capitalists' saving propensity matter; the same result as in Kalecki and Keynes! The model was then reprised by Pasinetti (1962), who had identified a "logical drift," but whose correction does not change Kaldor's main conclusion. For that reason we refer to an integrated "Kaldor-Pasinetti" model.

\footnotetext{
${ }^{8}$ Solow (1956) uses a Cobb-Douglas production function which by nature (or technical feature) assumes constant relative factor shares. This is not withstanding Solow's own skepticism in the constancy of such shares (Solow 1958). See section 6 for further details.
} 


\subsection{Stylized Facts}

Kaldor's $(1956,1957)$ model discusses the features of an economy in a steady state position. The economy grows at a constant rate given by population, technological progress and investment. Resources are fully utilized and full employment prevails "in general" (see caveat below). All this is derived from Kaldor's assumptions, which he only made explicit later (Kaldor, 1961):

1. Constant labor productivity (output per capita),

2. Consistent capital productivity, hence

3. Constant capital-labor ratio,

4. Constant distribution of income,

5. Relative stability of real interest rates, and finally

6. Existence of large disparities in the rate of productivity growth.

Following Harrod (1939) this implies that the economy's growth path is stable if warranted savings are actually achieved. But how?

\subsection{The Model}

Kaldor extends Harrod's theory by using the fact that any savings rate provides a split of income between consumption and savings which is different for each social group. Kaldor uses two identities:

$$
\begin{gathered}
Y \equiv W+\Pi \\
S \equiv S_{w}+S_{c}
\end{gathered}
$$

where, $S_{W}$ and $S_{C}$ are the savings amounts provided respectively by workers and capital-owners. Assuming that the only source of income for these two classes are wages and profits, the savings rate of the two social categories is defined as:

$$
s_{w}=S_{w} / W \text {, and } s_{c}=S_{c} / \Pi
$$


And in a closed economy without government savings equals investment $(I)$, so that

$$
I \equiv S=S_{w}+S_{c}=s_{w} W+s_{c} \Pi
$$

Rewriting,

$$
I=s_{w} Y+\left(s_{c}-s_{w}\right) \Pi
$$

Solving for the profit share we get Kaldor's famous equation

$$
\frac{\Pi}{Y}=\frac{1}{s_{c}-s_{w}} \frac{I}{Y}-\frac{s_{w}}{s_{c}-s_{w}}
$$

Since the share of profits cannot be negative or zero, we must add the condition

$$
0<s_{w}<\frac{I}{Y}<s_{c}<1
$$

Thus, provided that equations (20) and (21) are verified, which they necessarily are since they come from an identity, the savings rate in the economy is going to the one matching the natural rate of growth, so that the economy will be on a persistent, stable, full employment, growth path.

\subsection{The Pasinetti Critique}

Pasinetti (1962) complements Kaldor's model six years after its publication, having identified a "logical drift" leading to an "absurdity": if people save, they become owners of capital and they have to be compensated accordingly. A portion of profits must be attributed to workers; otherwise, workers have no motivation to save. This addition to Kaldor's theory did not change much of the key findings, hence the name Pasinetti paradox. The share of total profits in value added remains the same, with the same determinants, method and with the same assumptions. To see why, consider equation (18) which becomes 


$$
\begin{gathered}
S \equiv S_{w}+S_{K}=s_{W}\left(W+\Pi_{W}\right)+s_{K} \Pi_{K} \\
S=I=s_{W} Y+\left(s_{K}-s_{W}\right) \Pi_{K}
\end{gathered}
$$

where the subscripts $W$ and $K$ denote variables for workers and capital-owners, respectively. Solving for the profit share we get

$$
\frac{\Pi}{Y}=\frac{1}{s_{K}-s_{w}}\left[\frac{I}{Y}-s_{W}+r \cdot s_{w}\left(s_{K} \frac{I}{K}-\frac{K}{Y}\right)\right]
$$

where $r$ is the interest rate, i.e. the rate at which workers extend loans to capital-owners. Pasinetti remarks that in the long run the interest rate must equal the rate of profit, in which case, after a long derivation, we get the same result that Kaldor arrived at:

$$
\frac{\Pi}{Y}=\frac{1}{s_{K}} \frac{I}{Y}
$$

Pasinetti presents an approach that is more complete but arrives at the same result. The most striking conclusion remains that workers can in no way influence the distribution between wages and profits. And the savings rate of workers still cannot influence the macroeconomic division between wages and profits, which is solely determined by the decisions of capitalists. Kaldor's rule (attributed to Kalecki, and which is also present in the parable of the widow's cruse of Keynes) remains true: workers spend what they earn and capitalists earn what they spend. Table 1 summarizes the different values of the profit share according to three cases studied by Kaldor and Pasinetti.

Kaldor and Pasinetti arrive at the conclusion that a balanced growth path and full employment are consistent with a single rate of profit and a certain level of income distribution. The sustainability of the balanced growth path is maintained by the realization of the profit rates described in Table 1 (below). 
Table 1 Formula Summary for Profit Shares and Profit Rates in Kaldor and Pasinetti

\begin{tabular}{|c|c|c|}
\cline { 2 - 3 } \multicolumn{1}{c|}{} & Profit share $\Pi / Y=$ & Profit rate $\Pi / K=$ \\
\hline General case & $\frac{1}{s_{c}-s_{w}} \frac{I}{Y}-\frac{s_{w}}{s_{c}-s_{w}}$ & $\frac{1}{s_{c}-s_{w}} \frac{I}{K}-\frac{s_{w}}{s_{c}-s_{w}} \frac{Y}{K}$ \\
\hline Special case $s_{w}=0$ & $\frac{1}{s_{c}} \frac{I}{Y}$ & $\frac{1}{s_{c}} \frac{I}{K}$ \\
\hline Special case $s_{w}=0$ and $s_{c}=1$ & $\frac{I}{Y}$ & $\frac{I}{K}$ \\
\hline
\end{tabular}

\subsection{Full Employment vs. Harrodian Dynamics}

The dynamics along the natural growth path are better explained in reference to the work of Harrod, who introduces three growth rates:

- The actual growth rate $g$,

- The natural growth rate, $g_{n}$, necessary to achieve or maintain full employment,

- And finally the warranted growth rate, $g_{w}$, which is the rate of investment in the total desired product. Harrod decomposes the investment rate as:

$$
\frac{I}{Y}=\frac{I}{K} \frac{K}{Y}=\frac{S / Y}{\sigma}=s . \sigma^{-1}
$$

with $\sigma:=\frac{1}{A_{K}}=\frac{K}{Y}$

The warranted growth rate is $g_{w}=s / \sigma$; it is the output growth rate compatible with entrepreneurs' investment. To Harrod, most entrepreneurs are optimistic; they anticipate profit from increased production prospects and the more they invest the higher the warranted growth rate. 
To achieve balanced growth and full employment in Harrod's model, we need the three growth rates to be equal: $g=g_{w}=g_{n}$. This requires that the expectations of entrepreneurs generate an actual growth rate that coincides perfectly with the natural growth rate. Harrod points out that this case is unusual, historically, and there is no reason for this to happen automatically and always. As a result, full employment is not the norm.

The theoretical framework of full employment advanced by Kaldor thus appears as the particular, ideal case; a case rarely considered by Harrod. Kaldor only introduces the possibility of a minor imbalance. Kaldor introduces the realization of $S=I$ ex-post and introduces the possibility of a slight deviation $S \neq I$ ex-ante. What will happen if the system is close to, but not in, equilibrium?

When investment is higher than savings, the excess demand generates inflation in the consumer goods sector. With sticky nominal wages, inflation lowers real wages, with two major consequences. First, a rising price of consumer goods leads to income consisting of a smaller proportion of consumption and a greater share of savings. Second, a lower real wage rate leads to a lower labor productivity in perfect competition, which restores the constancy of the share of profits. Therefore, and whichever way, Kaldor's model presents the peculiarity that a slight imbalance is automatically compensated for by price adjustment.

\subsection{A Full Employment Keynesian Model}

Kaldor and Pasinetti's approach to income distribution follows the Keynesian tradition in the very particular context of the "stylized facts," namely, assuming full employment. It is therefore not true in the general case, as Keynes believed that full employment occurs only "by chance," and that it is rare that $g=g_{n}=g_{w}$. Despite this criticism, Kaldor $(1956,1957,1961)$ remained faithful to the assumption of full employment.

Kaldor has been strongly criticized for this assumption. Samuelson (1964b) refers to Kaldor as "Jean-Baptiste Kaldor" (p.345). Weintraub (1981) quipped "Lord Kaldor, in his cheering section, highlights a defined share of the profits of the original application [investment], or savings, [theory] deficient for many because of its foundations [in terms] of full employment". Marglin (1984) points out that the assumptions Kaldor makes are "more neoclassical than neo-Keynesian" (p.534). From the point of view of this assumption of full employment, Pasinetti is more explicit than Kaldor. 
One can make the following comments, all being equivalent:

1. Consequences of Kaldor's stylized facts:

(a) The assumption of balanced growth implies the realization of full employment.

(b) Kaldor is not interested in the ups and downs of the economy as it is assumed to be stable in a long run.

(c) The central question is whether the savings rate (thus, incidentally, the distribution and rate of return) accompanies or helps maintain full employment growth, as opposed to how to achieve full employment from a situation of unemployment.

2. The distribution theory presented by Kaldor is the result of the savings of workers and capitalists which generate a certain level of fully invested savings. This investment comes with a certain level of economic growth, which is fixed by assumption. The distribution of income resulting from investment decisions must be such that the share of profits accommodates a constant growth. Therefore, for Kaldor, the distribution of income does not allow for the achievement of stable growth or full employment, since by assumption, growth is stable and full employment is realized.

3. Income distribution has an endogenous role of proportionality that cannot explain the fluctuations in the growth rate. Near full employment, there is a certain growth rate accompanied by a certain distribution, the two being in a constant ratio.

4. Kaldor's model is an ergodic model: the future is a continuation of the past, through an automatic (price!) adjustment mechanism. There is no regime change in which accumulation is endogenous, and the possibility of underemployment is not taken into consideration.

Such specific assumptions limit the reach of Kaldor's model. One may even wonder what the real Keynesian content of the model is. Is the model in the form of a "synthesis"? Nevertheless, it does not contradict the spirit of Keynes's view of full employment, a situation in which Keynes saw "no objection” to neoclassical economics. This suggests that Keynes and Kaldor are in agreement with the neoclassical authors in regards to full employment; income distribution plays an accompanying role—not a determining role. 
Kaldor's model, confined as it is, introduces three major insights. First is the introduction of distribution in the economic discourse, which is underlying but not explicit in the work of Keynes. Second: the conclusion that workers spend what they get and capitalists get what they spend, is maintained. Third, even in a situation of full employment, it is demand that is driving the activity in Kaldor's system - just a level of demand that is assumed to be always right, as implied by the above equations. 


\section{THE INCOME DISTRIBUTION BUSINESS CYCLE MODEL OF RICHARD GOODWIN}

Goodwin's (1967) model addresses some of the shortcomings of Kaldor's model. Full employment is no longer assumed; the framework is not long-term growth, and income distribution is no longer passive. Instead, Goodwin develops a class struggle model in which workers and capitalists clash over income distribution. This leads to an income distribution cycle generated and endogenously maintained by employment and growth.

\subsection{The Model}

Goodwin's model is based on the following causal chain. At high levels of employment, upward-wage pressure starts to appear; the profit share is compressed which limits investment and therefore employment. But at that point the scarcity of jobs creates de facto the conditions of the restoration of the share of profits and the restoration of growth and employment.

Goodwin begins his presentation by specifying the limits and assumptions of his analysis: "the model presented here is completely diagrammed and [is] as a rather unrealistic model of growth cycles" (p.54). Similar to Kaldor (1956), Goodwin provides precise assumptions “made for reasoning practices":

1. Technical progress changes at a constant rate. Or;

2. Labor grows at a constant rate

3. Only two factors of production exist: labor and "capital"

4. All amounts are expressed in real and net terms

5. All wages are consumed

6. Productivity of capital is constant: $A_{K}=\frac{Q}{K}=\frac{1}{\bar{\sigma}}$

7. The real wage rate increases near full employment.

The first equation in this context captures the increase in the capital stock of the investment (which is the savings by identity). The author assumes that all profits are invested:

$$
\frac{\partial K}{\partial t}=I=S=\Pi=\left(1-\frac{w_{g}}{A_{L}}\right) Q
$$


where $w_{g} / A_{L}$ is the wage share prevailing at full employment. Dividing through by $K$, we simplify the previous equation:

$$
\dot{K}=\frac{\frac{\partial K}{\partial t}}{K}=\left(1-\frac{w_{g}}{A_{L}}\right) \frac{Q}{K}
$$

where a dot above a variable indicates the rate of change of that variable from time $t$ to $t+1$. As before, we rename $\frac{Q}{K}=\frac{1}{\bar{\sigma}}$, which is constant following assumption $H 1$, so that

$$
\dot{K}=\left(1-\frac{w_{g}}{A_{L}}\right) / \bar{\sigma}
$$

The rate of productivity growth is the gap between the growth rate of output and the growth rate of employment. Since the growth rate of labor productivity is constant (as a result of H1 and H6).

$$
\dot{Q}-\dot{N}=\overline{\dot{A}}_{L}
$$

Since in the current framework any supplemental growth can only be achieved by extra investment, $\dot{Q}=\dot{K}$, then (30) may be rewritten as

$$
\dot{K}-\overline{\dot{A}}_{L}=\dot{N}
$$

Combining (29) and (31), we find that

$$
\dot{N}=\left(1-\frac{w_{g}}{A_{L}}\right) / \bar{\sigma}-\overline{\dot{A}}_{L}
$$


Since both capital and labor feature constant productivity, equation (32) implies that the growth rate of employment is a decreasing linear function of the labor share in total income, $\alpha=\frac{w_{g}}{A_{L}}$.

Denoting the labor force $L$, the rate of employment variable $\mu$ is introduced as $\mu \equiv N / L$, $\dot{\mu} \equiv \dot{N}-\overline{\dot{L}}$. Combining this last identity with (32), it follows that

$$
\dot{\mu}=\frac{1-\alpha}{\bar{\sigma}}-\left(\overline{\dot{A}}_{L}+\overline{\dot{L}}\right)
$$

Goodwin's model assumes that the real wage rate increases in the neighborhood of full employment. Hypothesis $H 7$ is interpreted with reference to Marx's theory of a reserve army and the empirical work of A.W. Phillips. Goodwin assumes an approximate growth rate of real wages by a linear function of the rate of employment:

$$
\dot{\alpha}=(-a+b \mu)-\overline{\dot{A}}_{L}
$$

Equations (33) and (34) are two differential equations which explain, respectively, the growth in the employment rate and the growth of the wage share. We can rewrite those relationships in a dynamic systems form:

$$
\begin{gathered}
\left\{\begin{array}{l}
\dot{\mu}=\frac{1-\alpha}{\bar{\sigma}}-\left(\overline{\dot{A}}_{L}+\overline{\dot{L}}\right) \\
\dot{\alpha}=(-a+b \mu)-\overline{\dot{A}}_{L}
\end{array}\right. \\
\Leftrightarrow\left\{\begin{array}{l}
\frac{\partial \mu}{\partial t}=\left[\frac{1-\alpha}{\bar{\sigma}}-\left(\overline{\dot{A}}_{L}+\overline{\dot{L}}\right)\right] \mu \\
\frac{\partial \alpha}{\partial t}=\left[(-a+b \mu)-\overline{\dot{A}}_{L}\right] \alpha
\end{array}\right.
\end{gathered}
$$


Goodwin notes that the last rewriting is of a most common type of differential equations called Lotka-Volterra also known as predator-prey models. Such system is represented by a phase diagram characterized by a cycle and an equilibrium point (see Figure 2).

Figure 2 The Goodwin Cycle

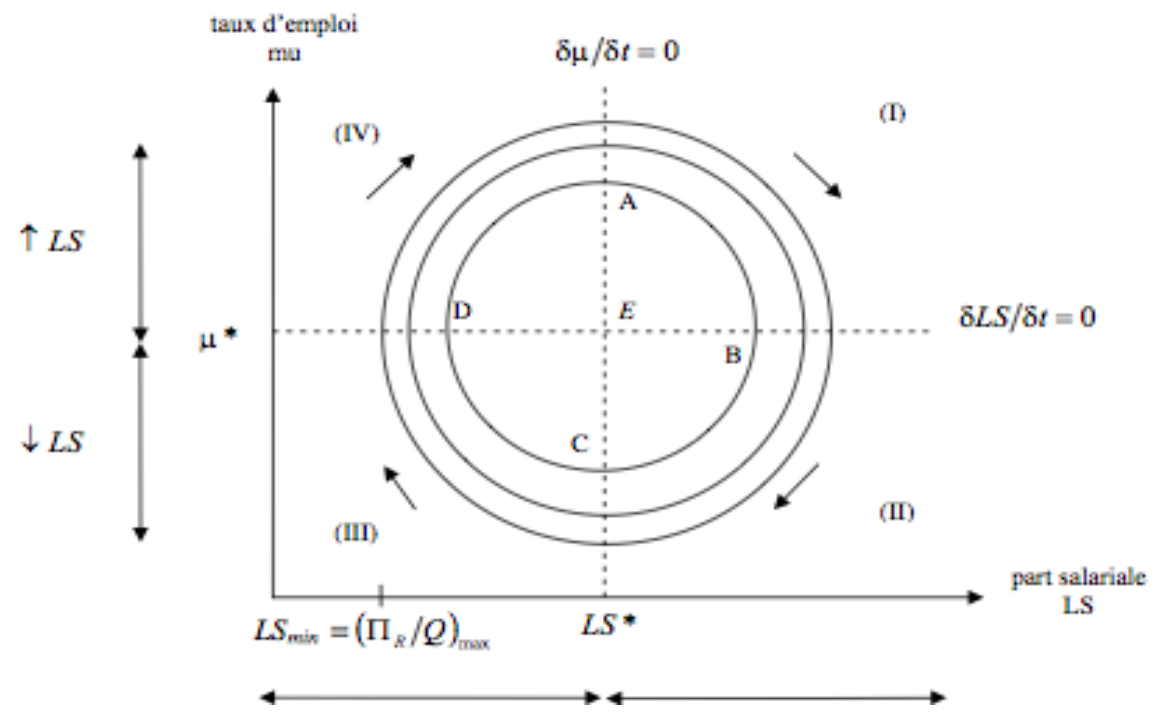

\subsection{Solution and Interpretation}

The equilibrium point $E$ is the solution that simultaneously cancels the LHS of equations (36):

$$
\left\{\begin{array} { l } 
{ \frac { \partial \mu } { \partial t } = 0 } \\
{ \frac { \partial \alpha } { \partial t } = 0 }
\end{array} \Leftrightarrow \left\{\begin{array}{c}
\alpha^{*}=1-\left(\overline{\dot{A}}_{L}+\overline{\dot{L}}\right) \bar{\sigma} \\
\mu^{*}=\left(a+\overline{\dot{A}}_{L}\right) / b
\end{array}\right.\right.
$$


The models' features are that

- The solution, or equilibrium, is never reached but there is a constant movement around it. The equilibrium point $E=\left(\alpha^{*}, \mu^{*}\right)$ is better seen as an "average"; the average of the labor share and the employment rate over the business cycle. What is remarkable is that this equilibrium is stable and independent of initial conditions, as pointed out by Goodwin (p.58). The direction of rotation $A \rightarrow B \rightarrow C \rightarrow D \rightarrow A$ on Figure 2 is given by the sign of the model parameters.

- Contrary to the equilibrium, the amplitude of the cycle does depend on the initial conditions, so that starting from a very high wage share will make the cycle last longer. Whereas there is only one equilibrium point, there may be several cycles for different initial conditions.

- The circular shape of the trajectories is due to the fact that we have assumed (or made it in such a way) that the relationships between the $(\alpha, \mu)$ variables are linear. For nonlinear relationships we would have led to concentric oval or ellipsoidal shapes. Finally, the cycle is a closed cycle in Goodwin's model: the model has the particular feature that, whatever the initial conditions $\left(\alpha_{0}, \mu_{0}\right)$, we return to the starting point.

The usual interpretation of the equations of Volterra type is that of predator-prey model, which is in line with a Darwinian interpretation of the evolution and the preservation of species. A classic illustration of this type of model is two populations of shark and fish living in balance in a closed environment. Both populations have a common dynamic in the sense that if there is plenty of prey (fish), then predators (sharks) are increasing in numbers, whereas scarcity of prey implies a dwindling predator population. The converse is true for prey: the fish population increases when there are few predators and decreases if they are abundant. Both populations tend to over-react (overshoot) insufficient / excess of the other population. 


\subsection{Analysis and Contribution}

We can describe the economics of Goodwin's model using this analogy between fish and sharks. The employment rate represents the fish population, or prey, and the wage share represents the shark population, the predator. When the wage share is too high between $A$ and $C$ (i.e., superior to its equilibrium or average value), the employment rate decreases: the abundance of sharks is reducing the number of fish. Similarly, when the wage share is lower than average, such as between points $B$ and $D$, the employment rate increases: due to the small number of fish, the shark population increases).

Goodwin's model may also be interpreted in reference to economic conditions. From point $A$ to point $C$, the employment rate goes down from its maximum to its minimum (point $A$ can be seen as a peak of the cycle and point $C$ as the lowest point). This continued deterioration in the employment rate occurs when the wage share is superior to its equilibrium value $\alpha^{*}$; that is to say when the profit share is below its average. According to Goodwin (p. 58), downturns are due to the loss of profits. Conversely between point $A$ and $C$, the employment rate rises as the profit share rises.

In economic terms, the main features of the model can be summarized in five points:

1. By assumption, profits are assumed to be fully invested and wages entirely consumed. Goodwin does not raise the question of market outlets and eventual leakage out of the system, and their contractionary implications.

2. By assumption, labor productivity grows at a fixed rate. This assumption is similar to the one in Kaldor's model (1957), but since Goodwin does not assume a constant growth rate of production, then we must have cyclical fluctuations - see equation (30).

3. Corollary: cyclical fluctuations are a source of under-employment (in labor), because the growth rate of labor is constant.

4. Conclusion 1: The share of wages and the employment rate are interrelated: at times in a positive way (quadrants II and IV, second equation in (37)); at times in a negative way (quadrants I and III, first equation in (37)). According to Goodwin, the increase in employment can only occur when businesses become more profitable, that is to say, have a lower payroll / wages bill.

5. Conclusion 2: These two opposite effects compensate in time to form a dynamic, closed system. Whatever the set of initial conditions, it always returns to the starting point through 
rotation around the point of equilibrium.

In Goodwin's model, the distribution of income is endogenous, deeply embedded, and appears to function harmoniously with the economic system. It is not just accompanying the business cycle: income distribution is (a part of) the business cycle, since it is able to restore or deteriorate the level of production and employment.

Finally, we note that model is constructed so that there are closed trajectories around equilibrium. Employment growth is automatically restored by income distribution (i.e. an increase in the share of profits). This calls for three comments:

- If the equilibrium point $E=\left(\alpha^{*}, \mu^{*}\right)$ is unchanged, we should expect the distribution of income to be oscillating around a long-run constant. Goodwin's model cannot account for a permanent economic situation of underemployment. It could nevertheless be extended in that way by assuming that profits are not entirely re-invested, wages are not entirely consumed or any other kind of leakage.

- If the equilibrium point $E=\left(\alpha^{*}, \mu^{*}\right)$ could also be assumed changing due to changes in technology or other exogenously-defined variables.

- Finally, it is important to discuss the adequacy of applying the economic-biological model. The theory of the evolution of species is a naturalist theory. In the real biological world, there are also cases where species have disappeared even without human intervention. Not all economic models need to have closed dynamics. 


\section{TECHNOLOGY AND THE SHAPE OF THE PRODUCTION FUNCTION}

Until the laws of thermodynamics are repealed, I shall continue to relate outputs to inputs - i.e. to believe in production functions.

- Paul A. Samuelson (1972), p.174.

Technological progress has often been viewed as a central element of economic growth. In the most general sense, technological progress is based on the "yield" of the factors of production, i.e., the marginal products of capital and labor. And since marginal products can differ, technological progress can be biased towards either factor of production, and the relative shares will change. To understand how and in what direction, we need to discuss different types of technological progress and different types of production function.

Consider the most general aggregate production function:

$$
Y=F(L, Z, A)
$$

with two inputs: labor $L$, and a nondescript input $Z$ which could be capital, skilled labor or land. Parameter $A$ is a technology index featuring $\partial F / \partial A>0$ : a greater level of $A$ corresponds to "better technology" or "technological progress." The following definitions apply:

1. Factor augmentation: Technical change is said to be L-augmenting if the production function takes the more special form $Y=F(A L, Z)$, or $Z$-augmenting when $Y=F(L, A Z)$. We have factor augmentation when only one factor is affected by technological change.

2. Factor bias: $L$-biased technical change is different from being $L$-augmenting. We say that technological progress is $L$-biased when

$$
\frac{\partial}{\partial A} \frac{F_{L}{ }^{\prime}}{F_{Z}{ }^{\prime}}>0
$$

that is, if technical progress increases the marginal productivity of labor at a higher rate than it increases the marginal productivity of $Z$ (Acemoglu, 2002). 
Technological progress can be factor-biased:

- Technical progress is defined as Hicks-neutral if it does not affect the balance of labor and capital in the production function (Hicks, 1932). Since Hicksian neutrality implies that the marginal products of all factors increase at the same proportion, the production function can be written by factoring out technical progress such as $Y=A . F(L, Z)$.

- An innovation is Solow-neutral (Solow, 1969) if it only affects the productivity of capital: $Y=F(L, A Z)$.

- An innovation is Harrod-neutral (Harrod, 1942) if technology is labor augmenting: $Y=F(A L, Z)$.

\subsection{Production Functions: Cobb-Douglas vs. CES}

Two types of production functions stand out in the present context: the classic Cobb-Douglas (1928) and the Constant Elasticity of Substitution (CES). By modeling the growth of the American economy from 1899 to 1922, Cobb and Douglas (1928) proposed a simplified view of the economy where the level of output is determined by the amount of labor and capital involved in the production process. In the case of two factors and technical progress (later added in the function by Solow 1956), the standard Cobb-Douglas form is:

$$
Y=F(L, K)=A L^{\alpha} K^{\beta}
$$

where $Y$ represents total production, $L$ is the labor input, measured by the total number of person-hours worked in a year; $K$ is the capital input, measured by the monetary worth of all machinery, equipment and buildings; $A$ represents total factor productivity, and (which can be intangible as it can range from technology to human capital).

Finally, $\alpha$ and $\beta$ are the output elasticities of labor and capital, respectively, i.e., they measure the responsiveness of output to a change in the levels of either the labor or the capital input, ceteris paribus. For instance, if $\alpha$ equals 0.64 , a $1 \%$ increase in labor usage would lead to a $0.64 \%$ increase in output. In the case of an economy in perfect competition, the factors are paid at their marginal product, so that 


$$
\left\{\begin{array}{l}
\frac{W}{Y}=\frac{w}{Y} L=\frac{F_{L}^{\prime}}{Y} L=\frac{\alpha A L^{\alpha-1} K^{\beta}}{A L^{\alpha} K^{\beta}} L=\alpha \\
\frac{\Pi}{Y}=\frac{r}{Y} K=\frac{F_{K}^{\prime}}{Y} K=\frac{\beta A L^{\alpha} K^{\beta-1}}{A L^{\alpha} K^{\beta}} K=\beta
\end{array}\right.
$$

The Cobb-Douglas production function is particularly interesting in the case of perfect competition, in which case the function has the following features:

- The factor shares are directly readable on the production function itself as the capital and labor exponents,

- $\alpha$ and $\beta$ must be constant, or else the derivation above does not hold,

- Since aggregate income is composed of wages and profits and nothing else, it must be that $\alpha+\beta=1$,

- As a consequence, a perfectly competitive economy characterized by a Cobb-Douglas production function features constant returns to scale. ${ }^{9}$

Another way of proving this result is to call upon the so-called Euler theorem (one of many) stating that for a continuous function $y=f\left(x_{1}, \ldots, x_{n}\right)$ homogenous of degree one, i.e., featuring constant returns to scale, we have

$$
Y=\sum \frac{\partial y}{\partial x_{i}} x_{i}
$$

On one hand we can apply this theorem on a production function such as $Y=F(K, L)$ to get

$$
Y=\frac{\partial Y}{\partial L} L+\frac{\partial Y}{\partial K} K
$$

\footnotetext{
${ }^{9}$ A production function $Y=F(K, L)$ whose inputs are each multiplied by a scalar $\lambda$ implies, in the case of a Cobnb-Douglas case, that $\mathrm{F}(\lambda \mathrm{K}, \mathrm{KL})=\left(\lambda \mathrm{K}_{-}\right)^{\beta}(\lambda \mathrm{L})^{\alpha}=\lambda^{\alpha+\beta} \cdot \mathrm{K}^{\beta} \mathrm{L}^{\alpha}=\lambda^{\alpha+\beta} \cdot \mathrm{F}(\mathrm{K}, \mathrm{L})$

If $\alpha+\beta=1$, doubling the amount of capital and labor used in the production process will result in a doubled output and the production function displays constant returns to scale; if $\alpha+\beta<1$, the function has decreasing returns to sale; if $\alpha+\beta>1$, increasing returns to scale takes place.
} 
On the other hand, and by definition, we have

$$
Y=w \cdot L+r \cdot K
$$

By identification, it must be that $\frac{\partial Y}{\partial L}=w$ and that $\frac{\partial Y}{\partial K}=r$ or, in other words, it must be that factors are paid at their marginal product.

Summarizing: the Cobb-Douglas production function has such a particular form that the factor shares are constant in perfect competition, i.e., factors are paid at their marginal product and we have constant returns to scale. If more capital is used in the production process, the rate of profit $\Pi / K$ falls just enough to maintain a constant capital share.

\section{Cobb-Douglas + perfect competition $=$ constant labor share}

Another way to arrive at a constant distribution of income (see Gollin, 2007) is to use a production function with Harrod-neutral technical progress $Y=F(A L, K)$ in the Solow (1957) growth model. The production function $F(\cdot)$ need not be Cobb-Douglas. It is well-known that along the balanced growth path

$$
k^{*}=\frac{s}{\delta+g_{A}} f\left(k^{*}\right)
$$

where there is population growth, $s$ is the exogenous savings rate, capital depreciation is $\delta$, technical progress grows at a rate of $g_{A}, f$ features constant returns, and $k=K / A L$ is the capital stock per effective worker. Multiplying through by $r$ and rearranging we get the capital, or profit, share as

$$
\frac{r k^{*}}{f\left(k^{*}\right)}=\frac{s r}{\delta+g_{A}}
$$


which is necessarily constant on the balanced growth path because $s$ and $r$ are assumed constant. Thus, two very commonly used economic models, the Cobb-Douglas production function and the Solow growth model, feature a constant distribution of income. Factor shares are exogenous and have no driving role.

Another often-used production function is the Constant Elasticity of Substitution (CES) type. In the following pages we focus our attention on the classic CES production function; see Klump et al. (2011) for a survey of variations on the CES theme.

Pioneered by Arrow, Chenery, Minhas and Solow (1961), the classic CES production function is a "generalized Cobb-Douglas production function" as it encompasses the Cobb-Douglas as a special case. Mukerji (1963) considered a CES function for constant ratios of elasticity of substitution and Bruno (1962) suggested a generalization of CES production function to permit the elasticity substitution to vary. Thus, one of the most important differences between the Cobb-Douglas and CES production functions is that the former has a unit elasticity of substitution between labor and capital while the latter allows for non-unity elasticity.

The general two-factor CES production function takes the form of

$$
Y=A\left[\theta K^{\gamma}+(1-\theta) L^{\gamma}\right]^{1 / \gamma}
$$

Here $0<\theta<1$ is the relative share of capital and $\gamma$ captures the degree of substitutability of the inputs. Parameter $A$ depends upon the units in which the output and inputs are measured and is therefore not directly interpretable as technology. The value of $\gamma$ is equal to or less than 1 . Note that if unit elasticity of substitution prevails $\gamma=1$, the CES function collapses to the Cobb-Douglas form $Y=A K^{\beta} L^{1-\beta}$.

"Neoclassical" growth theory and the aggregate CES production function have a long common history, starting with Solow's (1956) seminal contribution (Klump et al., 2007). However, the workhorse of growth theory has tended to be the Cobb-Douglas. One reason for this general interest may reside in the long-held belief in a "stylized fact" of long-term economic growth: the approximate constancy of factor shares. We have already proved that an elasticity of substitution equal to unity, as suggested in the Cobb-Douglas production function, implies a constant factor share and a constant capital-to-labor ratio. Any changes in factor proportions will be exactly offset by changes in the marginal product of the factor inputs (Miller, 2008). In the case 
of a CES production function, since the elasticity of substitution need not be unity, a constant factor income share can only be achieved if technological progress is purely Harrod-neutral (Klump et al., 2007).

\subsection{Technical Change in the CES Production Function}

Consider the previous CES production function with $\gamma=\frac{\sigma-1}{\sigma}$

$$
Y=A\left[\theta\left(A_{L} L\right)^{\frac{\sigma-1}{\sigma}}+(1-\theta)\left(A_{Z} Z\right)^{\frac{\sigma-1}{\sigma}}\right]^{\frac{\sigma}{\sigma-1}}
$$

By construction, $A_{L}$ and $A_{Z}$ are two separate technology terms, and $A_{L}$ is $L$ -augmenting, while $A_{Z}$ is $Z$-augmenting. ${ }^{10}$ Parameter $\theta$ captures the relative importance of the two factors and $\sigma \in[0,+\infty[$ is the elasticity of substitution between labor and variable $Z$. This quantity measures the extent to which firms can substitute capital for labor as the relative productivity or the relative cost of the two factors changes.

The elasticity of substitution is defined as

$$
\sigma=\frac{\partial \ln \frac{Z}{L}}{\partial \ln \frac{M P_{L}}{M P_{Z}}}
$$

- When the two factors are perfect substitutes, $\sigma=+\infty$, the production function becomes linear: $Y=\theta A_{L} L+(1-\theta) A_{Z} Z$ and the isoquants are straight (see Figure 3 . The marginal rate of substitution of labor for capital at any point on an isoquant is a constant. The movement of the isoquants depends on the values of $A_{L}$ and $A_{Z}$.

${ }^{10} A_{L}$ is also $L$-complementary and $A_{L}$ is $Z$-complementary. 
Figure 3 CES Production Function and Perfect Factor Substitution

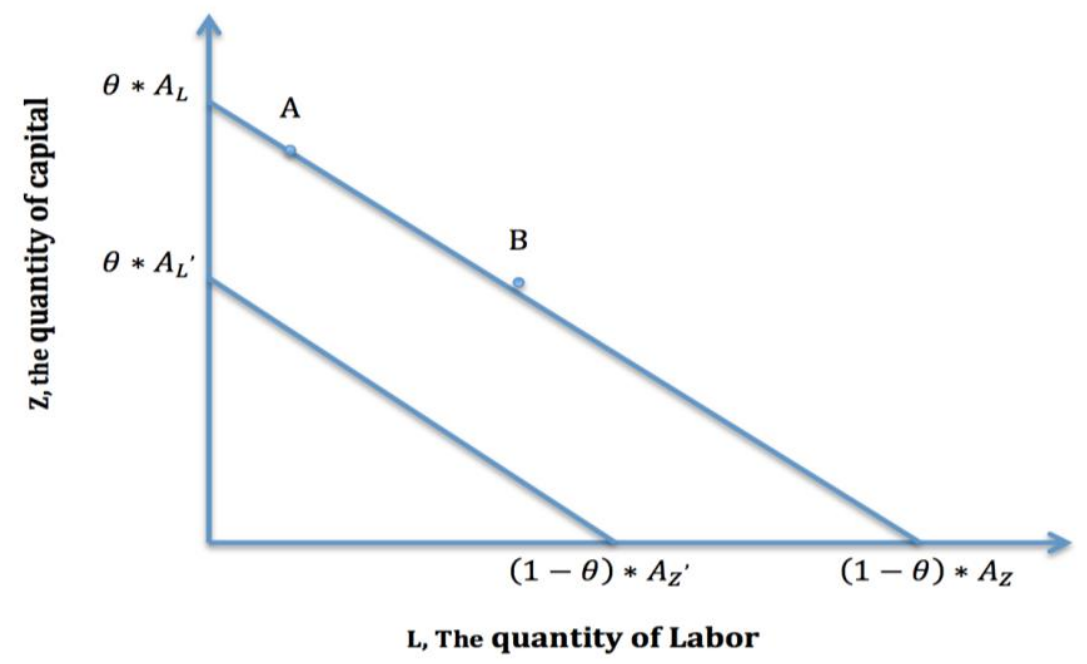

- When $\sigma=0$, there is no substitution between two factors.

- When $\sigma=1$, the production function is Cobb-Douglas.

The direction of the bias of technical change depends on the elasticity of substitution. To understand this, calculate the relative marginal product of the two factors (Acemoglu, 2002):

$$
\frac{M P_{Z}}{M P_{L}}=\frac{1-\theta}{\theta}\left(\frac{A_{Z}}{A_{L}}\right)^{\frac{\sigma-1}{\sigma}}\left(\frac{Z}{L}\right)^{-\frac{1}{\sigma}}
$$

As the relative quantity of factor $Z$ is increasing, $Z / L$ increases and its relative marginal product is decreasing (ceteris paribus). This is the usual substitution effect, leading to a downward sloping relative demand curve. The effect of $A_{Z}$ on the relative marginal product depends on $\sigma$ :

- When the two factors are gross substitutes $(\sigma>1)$, an increase in $A_{Z}$ relative to $A_{L}$ increases the relative marginal product of $Z$, so that a $Z$-augmenting technical change is also $Z$-biased.

- When the two factors are gross complements $(\sigma<1)$, which is usually the case (see Giovannoni [2013b] for an overview), the reverse holds: a $Z$-augmenting technical change is actually $L$-biased. Intuitively, in this case of complementarity, an increase in the productivity of $Z$ increases the demand for the other factor-labor-by more than the demand for $Z$, which 
creates "excess demand" for labor. As a result, the marginal product of labor increases by more the marginal product of $Z$ (Acemoglu, 2002).

The value of the elasticity of substitution has been shown to play a critical role in influencing economic growth and the movements of the labor share (Irmen, 2011; Choi and Rios-Rull, 2009). Both non-competitive factor prices and a non-unit elasticity of substitution can explain the dynamics of the labor share, and the latter seems more important. Raurich et al. (2012) derive the equation of the labor share when there is imperfect competition, and labor-augmenting technology, so that the production function is

$$
Y=A\left[\theta L^{\frac{\sigma-1}{\sigma}}+(1-\theta)\left(A_{L} Z\right)^{\frac{\sigma-1}{\sigma}}\right]^{\frac{\sigma}{\sigma-1}}
$$

Following Galí (1996) we obtain the labor share $\alpha_{t}$ as

$$
\alpha_{t}=\frac{w_{t} L}{Y_{t}}=\frac{1-\theta}{m_{t}}\left(\frac{Y_{t}}{A_{L} L}\right)^{\frac{1-\sigma}{\sigma}}
$$

This equation clearly shows that the labor share depends on:

- The evolution of the markup $m_{t}$

- The average labor productivity in efficiency units, $Y_{t} /\left(A_{L} L\right)$, when $\sigma \neq 1$

Further, the average productivity can be written as

$$
\left(\frac{Y_{t}}{A_{L} L}\right)^{\frac{1-\sigma}{\sigma}}=\frac{1}{\theta\left(\frac{Z_{t}}{A_{L} L_{t}}\right)^{\frac{\sigma-1}{\sigma}}+(1-\theta)}
$$

so that the labor share can be rewritten as 


$$
\alpha_{t}=\frac{1}{m_{t}} \frac{1-\theta}{\theta\left(\frac{Z_{t}}{A_{L} L_{t}}\right)^{\frac{\sigma-1}{\sigma}}+(1-\theta)}
$$

The last equation indicates a relationship between the labor share and capital deepening that depends on the value of $\sigma$. Capital deepening, or capital intensity, refers to the accumulation of capital per effective worker. If $\sigma>1$, capital deepening reduces the labor share, and if $\sigma<1$, capital deepening increases the labor share.

Table 2 summarizes the movement of labor and the direction of technical bias given the value of $\sigma$ for the case of a capital-augmenting technology.

Table 2 The Elasticity of Substitution and the Labor Share of Income

\begin{tabular}{|c|c|c|c|}
\cline { 2 - 4 } \multicolumn{1}{c|}{} & $\begin{array}{c}\boldsymbol{\sigma}>\mathbf{1} \\
\text { Factors are } \\
\text { substitutes }\end{array}$ & $\boldsymbol{\sigma}=\mathbf{1}$ & $\begin{array}{c}\boldsymbol{\sigma}<\mathbf{1} \\
\text { Factors are } \\
\text { complements }\end{array}$ \\
\hline $\begin{array}{c}\text { Capital deepening } \\
\text { leads to ... }\end{array}$ & $\begin{array}{c}\text { Capital-biased } \\
\text { Technology, } \\
\text { lower labor share }\end{array}$ & $\begin{array}{c}\text { Neutral } \\
\text { Technology, } \\
\text { constant labor share }\end{array}$ & $\begin{array}{c}\text { Labor-biased } \\
\text { Technology, } \\
\text { higher labor share }\end{array}$ \\
\hline
\end{tabular}

\subsection{Criticisms of the Cobb-Douglas Form}

I personally have faith that there is a fundamental unity in economic as in physical life [...] There is law and relative regularity everywhere else - why not in production and distribution?

- Paul Douglas (1967), p. 22

There are reasons to be skeptical that the Cobb-Douglas production function provides an entirely satisfactory approximation to reality, however. First, most estimates suggest that the aggregate elasticity of substitution is significantly less than 1. Second, a production function with an elasticity of substitution of 1 does not provide a framework for analyzing fluctuations in factor shares, such as those [observed in reality]

- Daron Acemoglu (2003), p. 3 
Even though the Cobb-Douglas form was supported by the data from 1899-1922, its accuracy in different industries and time periods has been called into question. It is clear that the model lacks micro-foundations. The function assumes that the labor and capital shares of total output are constant over time, which is not always true and has not always been true in every circumstance that the function was taken to the data (see Giovannoni 2014c). Neither Cobb nor Douglas provided any theoretical reason why the coefficients $\alpha$ and $\beta$ should be constant over time or be the same among different sectors of the economy. Those are mathematical imperatives, not economic imperatives.

The use of macroeconomic production functions spread following Solow's (1957) classic growth model was introduced. It is rarely noticed that shortly afterwards Solow (1958) qualified the constancy of relative shares as "a mirage" and was implicitly skeptical about the use of such aggregated production functions.

Numerous studies have tried to assess whether the Cobb-Douglas or the CES production function was more appropriate to macroeconomic forecasting. Miller (2008) finds that the strength of the Cobb-Douglas is its ease of use and its seemingly good empirical fit across many data sets. Unfortunately, the fact that the Cobb-Douglas model also fits the data well in cases where some of its fundamental assumptions are violated suggests that many empirical tests of the Cobb-Douglas model are picking up a statistical artifact rather than an underlying production function.

Similar results can be traced back to Shaikh (1974), who criticized the Cobb-Douglas production function for having a weak theoretical basis - it is an identity, really. Shaikh shows that the empirical results do not in fact have much to do with production conditions at all. Instead, Shaikh shows that when factor shares are constant, there are broad classes of production data (output, capital, and labor) which can always be related to each other through a functional form mathematically identical to a Cobb-Douglas function with "constant returns to scale," "neutral technical change," and "marginal products equal to factor rewards." 
Fraser (2002) paid attention to the issue of whether the data provides deductive support for the "laws of production" as claimed by Cobb and Douglas (1928). Only the New South Wales data and, to a lesser extent, the New Zealand data produce supportive results. Moreover, Fraser ran collinearity diagnostics to reexamine the original series studied, and the result shows all data are subject to collinearity and that the time series properties raise questions as to the statistical robustness of the estimates presented by Douglas.

Another criticism of the Cobb-Douglas production function rests in his possible misinterpretation of technical progress (Miller, 2008). The majority of production functions assume that technical progress is Hicks-neutral, which does not change the marginal products of capital or labor given a certain ratio of inputs. Because of such a strong assumption, it can be shown that Cobb-Douglas is the only functional form that is able to explain the U.S. experience of constant factor shares and a rising capital-labor ratio (Antràs 2004). However, this is simply because Cobb-Douglas is the only functional form where Hicks-neutrality can be equivalently expressed as labor-augmenting technical change. Antràs (2004) also suggests that the finding of the constant shares in many older econometric investigations may be due to an omitted-variable bias caused by the assumption of Hicks neutral technical change.

Furthermore, Raval (2011) found that the Cobb-Douglas production function has two empirical implications that do not hold in the data: a constant cost share of capital and a strong co-movement in average revenue product of capital and average revenue product of labor. Raval finds that the cost shares of capital are different within four-digit-SIC (standard industry code) industries, so simply assuming that they are constant can lead to an estimation bias. Also, the average revenue product of labor is found to increase much more with revenue than the revenue product of capital.

Finally, there is the concern of short-run versus long-run breadth of analysis. Did the empirical investigations into the Cobb-Douglas form and into factor share feature enough datapoints? Surely the Cobb-Douglas results hold only in the long run, but how long is the long run? 
Swimming against the current, Jones (2003) presents a defense of the Cobb-Douglas production function by presenting readers with four stylized facts:

- The growth rate in U.S. GDP per capita has not shown a considerable trend for the last 125 years.

- The capital share shows a significant trend in many countries and in many U.S industries over time.

- The estimates of the elasticity of substitution between capital and labor are often below unity.

- The price of capital goods in the "equipment" category, such as computers, machine tools, has been falling relative to the price of nondurable consumption goods, where the falling price is taken to indicate that technical progress is being embodies in capital goods at a faster rate than in consumption goods.

Jones (2003) then attempts to reconcile the above facts with a Cobb-Douglas function despite these facts not being compatible with it. However, this attempt is cut short by Chirinko (2002) which finds the value of the elasticity is still significantly below unity in the short run and in the long run. Thus, capital and labor are found to be complements, and capital deepening leads to a higher labor share because technological progress is labor-biased.

Comparatively, the CES production function has less restrictive assumptions about the interaction of capital and labor in production, but its data fit is inferior. One possible reason may be that various studies are not all measuring the same thing. The CES production function contains a number of variants that can be tested with either cross-sectional or time-series data. Klump and de La Grandville (2000) suggest that cross-study results would be much more meaningful when they are within the same CES family.

Moreover, the inefficiency of CES results can be attributed to the fact that time series estimates of the elasticity of substitution are not well measured by least squares regression. Klump and Preissler (2000) found that not all variants of CES functions commonly used are consistently specified. Therefore, there is no compelling evidence suggesting one should prefer CES to the Cobb-Douglas for forecasting GDP and income shares. However, since the seemingly perfect data fit of Cobb-Douglas is likely due to an accounting identity and mathematical feature rather than an underlying production function, the CES specification is probably getting better because of its allowance for a changing labor share and non-unitary elasticity of substitution, in a word, for being more general. 


\section{WHAT HAVE WE LEARNED? (NON)ERGODICITY AND THE ROLE OF ECONOMIC POLICY}

At the end of our inquiry it appears that there is no single model of income distribution that has emerged as a mainstream model (Kregel, 1973). The expression "model of income distribution" is an expression more true in plural form than in singular form. Consider the factors that each author introduces to explain factor shares:

- Keynes: capitalist propensity to consume

- Kalecki: degree of monopoly, ratio of raw materials prices to aggregate prices, capitalist consumption and investment

- Kaldor, Pasinetti: investment share of GDP, saving propensities

- Goodwin: employment ratio (itself a negative function of labor productivity, of labor supply, and of the productivity of capital, all three assumed constant)

- Technology: degree of substitution between factors, type of technological change

In addition, recall that the models are cast in either full-employment or imperfectly competitive frameworks, and that income distribution is alternatively constant, drifting or cyclical around full employment. How can we reconcile such different frameworks and models?

The present survey and summary can leave the reader feeling one of several ways. An avid reader is probably happy to learn about the many facets of the economics of factor shares. However, it is easy to get lost, overwhelmed or exasperated by the diversity and cacophony of the main theoretical models. A critical reader will note, despairingly, that the theoretical approaches detailed above are just that: theoretical. In practice there is no clear-cut division between aggregate labor income and aggregate profits. Economic theories have nothing to say about the apportionment of proprietors' income or the classification of interest income or the reason why the labor share seems to have fallen precipitously since the early 2000s. There is no consensus for this in the theoretical literature, when it even addresses such specific questions (Giovannoni 2014b).

Thus, it is hard to escape the conclusion that, in matters of factor shares, economic theories are useful but are not enough. The theory of international trade is more precise, the theory of economic growth is more developed, and so it goes with many other branches of economics. But we must go beyond those limitations. Is there a common thread to income distribution theories? 
As stated in the introduction, the ambition of this paper is to shed light on various theories, and then try to discern a pathway. Some decisive progress can be made by using a taxonomy based on the answers to the following two questions:

1. "Is income distribution assumed to be constant?" and

2. "Is income distribution treated as an exogenous factor (in the sense of driving the economy) or as an endogenous factor (adjusting to the rest of the economy)?"

Table 3 Suggested Taxonomy of Income Distribution Models

\begin{tabular}{cc|c|c|} 
& & \multicolumn{2}{|c|}{$\begin{array}{c}\text { Is income distribution assumed constant? } \\
\text { no }\end{array}$} \\
\hline \multirow{3}{*}{$\begin{array}{c}\text { The distribution } \\
\text { of income is... }\end{array}$} & exogenous (driving) & $\begin{array}{c}\text { Kalecki } \\
\text { Keynes }\end{array}$ & $\begin{array}{c}\text { Goodwin } \\
\text { (cycle around constant) }\end{array}$ \\
\cline { 2 - 4 } & endogenous (driven) & CES prod. function & $\begin{array}{c}\text { Cobb-Douglas } \\
\text { Kaldor-Pasinetti }\end{array}$ \\
\hline
\end{tabular}

The justification of the placement of each model is as follows, going clockwise from the top right cell. The Goodwin model presents a cyclical model where income distribution alternates as two driving variables with the employment ratio. The wage share is assumed constant on average. The labor share from either the Cobb-Douglas or CES production functions are driven by technology, which is the real force underlying the changes in income distribution. What income distribution drives, however, is not clear. Kaldor's model and Pasinetti critique make income distribution appear as a result of the investment and saving decisions of the economic agents. Those adjust to the slack on the labor market and devise the distribution of income which is compatible with full-employment. Thus income distribution in Kaldor-Pasinetti is "constant at full-employment" and adjusts ever so slightly to correct for any departure from full employment, as described in Kaldor (1956). Finally, for Kalecki, and seemingly for Keynes, the relative shares need not be constant but they are drivers of the whole economic system through, respectively, the degree of monopoly and the marginal propensity to consume. Note that there is no theory of income distribution in Keynes, but there is enough evidence to place him in the top left cell (see details in section 2). 
This taxonomy can be further refined by introducing the concept of (non)ergodicity as exposed, for instance, in Davidson (2003). An ergodic economic system is an economy whose future position is knowable in a deterministic way, possibly allowing for a stochastic error. In such a world, Davidson argues, economic policy and Keynes are irrelevant for there is a natural tendency of economies to self-correct. The future is knowable. Keynesian economics, Davidson continues, is inherently nonergodic - the future is unknowable and economic agents make decisions in radical uncertainty following rules of thumb and crowd movements.

It is the top left cell containing Kalecki and Keynes, and only this cell, which is compatible with the idea of non-ergodicity as in Davidson (2003). Other cells, particularly when income distribution is constant, are not compatible with nonergodicity: if income distribution is constant, or cyclical, or if it is assumed to adjust to maintain full employment, then income distribution in the future is knowable, and equilibrium will prevail. There is no need for economic policies except perhaps insofar as to expedite the process of convergence towards equilibrium. In those cases, income distribution is never "wrong" or inadequate, for it is the correct one that assures full employment of resources.

Income distribution can only be a problem, to the contrary, if one adopts a Keynesian or Kaleckian view of the economy. In those models income distribution can be inappropriate for full employment, and an income distribution policy could be desirable. For Keynes an inadequate distribution of income (outside of moral judgments) is one in which much income is diverted to individuals with a low marginal propensity to consume (MPC); for Kalecki, capitalists can confiscate much income to the detriment of workers. Hence the need of third actor, the State, which can institute redistribution policies, industrial organization policies such as introducing more competition, or introduce and support collective bargaining -among other possibilities. 


\section{REFERENCES}

Acemoglu, D. (2002) Directed Technical Change, The Review of Economic Studies, 69,4, 781-809

Antràs, P. (2004) Is the US Aggregate Production Function Cobb-Douglas? New Estimates of the Elasticity of Substitution, Contributions in Macroeconomics, 4, 1

Bertola G., R. Foellmi and J. Tweimuller (2006) Income Distribution in Macroeconomic Models, Princeton: Princeton University Press

Bertoli, S and F. Farina (2007) The functional Distribution of Income: a Review of the Theoretical Literature and of the Empirical Evidence Around its Recent Pattern in European Countries, Department of Economic Policy, Finance and Development, University of Siena, working paper 5/2007.

Bowley, A. (1900) Wages in the United Kingdom in the Nineteenth Century, Cambridge: Cambridge University Press

(1920) The Change in the Distribution of the National Income, 1880-1913, Oxford: Clarendon Press

(1937) Wages and Income in the United Kingdom since 1860, Cambridge: Cambridge University Press

Bruno, M. (1962) A Note on the Implications of an Empirical Relationship Between Output per Unit of Labor, the Wage Rate and the Capital-Labour Ratio, mimeo, Stanford University

Cobb, C. and P. Douglas (1928) A Theory of Production, The American Economic Review, 18, 1, $139-165$

Choi, S., and J.V. Rios-Rull (2009) Understanding the Dynamics of Labor Share: The Role of Noncompetitive Factor Prices, Annals of Economics and Statistics/Annales d'Économie et de Statistique, 95/96, 251-277

Chirinko, R. (2002) Corporate Taxation, Capital Formation, and the Substitution Elasticity Between Labor and Capital, National Tax Journal, 60, 339-355

Davidson, P. (1960) Theories of Aggregate Income Distribution, New Brunswick: Rutgers University Press (2003) Financial Markets, Money and the Real World, Cheltenham: Edward Elgar Publishing

Douglas, P. (1967) The Theory of Wages, New York: Kelley

Fraser, I. (2002). The Cobb-Douglas Production Function: an Antipodean Defense, Economic Issues, 7, 39-58 
Giovannoni (2014b) What Do we Know About the Labor Share and the Profit Share? Part II: Empirical Evidence, The Levy Economics Institute of Bard College, working paper No. forthcoming

(2014c) What Do we Know About the Labor Share and the Profit Share? Part III: Measures and Structural Factors, The Levy Economics Institute of Bard College, working paper No. forthcoming

Galí, J. (1996) Multiple Equilibria in A Growth Model with Monopolistic Competition, Economic Theory, 8, 251-266

Gollin, D. (2008) Labour's Share of Income, New Palgrave Dictionary of Economics, MacMillan

Goodwin, R. (1967) A Growth Cycle, in Feinstein (ed.) Socialism, Capitalism and Economic Growth, Cambridge University Press, Cambridge

Irmen, A. (2011) Steady-state Growth and the Elasticity of Substitution, Journal of Economic Dynamics and Control, 35, 8,1215-1228

Jones, C. (2003) Growth, Capital Shares, and a New perspective on Production Functions, mimeo, University of California, Berkeley

Harrod, R. (1939) An Essay in Dynamic Theory, The Economic Journal, vol. 49, 193, 14-33 (1948) Towards a Dynamic Economics, London: MacMillan

Hicks, J. (1932) The Theory of Wages, London: Macmillan

Kahn, R. (1931) The Relation of Home Investment to Unemployment, The Economic Journal, 41, $162,173-198$

(1933) The Elasticity of Substitution and the Relative Share of a Factor, The Review of Economic Studies, 1, 1, 72-78

Kaldor, N. (1956) Alternative Theories of Distribution, The Review of Economic Studies, 23, 2, 83-100

(1957) A Model of Economic Growth, The Economic Journal, 67, 268, 591-624

(1961) Capital Accumulation and Economic Growth, in Lutz \& Hague (ed.) The Theory of Capital, McMillan, London

Kalecki, M. (1935) Essai d'une Théorie du Mouvement Cyclique des Affaires, Revue d'Economie Politique, 49, 285-305

(1938) The Determinants of Distribution of the National Income, Econometrica, 6, 2, 97-112

(1942) A Theory of Profits, Economic Journal, 206/207, 258-267. Reproduced in 
Osiatynski J.(1990) Collected Works of Michal Kalecki, Clarendon Press, Oxford (1954) Theory of Economic Dynamics, London: Allen \& Unwin (1962) Studies in the Theory of Business Cycles, 1933-1939, London: Basil Blackwell

Keynes, J. M. (1930) A Treatise on Money, reproduced in volume V of Moggridge, D. (ed.) (1973) The Collected Writings of John Maynard Keynes, London: MacMillan (1936) The General Theory of Employment, Interest and Money, Harcourt, Brace \& World, New-York, 1997 Prometheus Books edition, New York: Armonk (1939) Relative Movements of Real Wages and Output, The Economic Journal, 49, 193, 34-51

Klump, R., P. McAdam and A. Willman (2007) Factor Substitution and Factor-Augmenting Technical Progress in the United States: a Normalized Supply-side System Approach, The Review of Economics and Statistics, 89, 1, 183-192

Klump, R. and H. Preissler (2000) CES Production Functions and Economic Growth, The Scandinavian Journal of Economics, 102, 1, 41-56

Klump, R. and O. de La Grandville (2000) Economic Growth and the Elasticity of Substitution: Two Theorems and Some Suggestions, American Economic Review, 90, 1, 282-291

Kregel J. (1971) Rate of Profit, Distribution and Growth : Two Views, London: MacMillan The Reconstruction of Political Economy, second edition (1975), London: MacMillan

Lopez, J. and M. Assous (2010) Michal Kalecki, Great Thinkers in Economics, New York: Palgrave MacMillan

Lucas, R. (2003) The Industrial Revolution: Past and Future, 2003 Annual report Essay, printed in the May 2004 issue of The Region, Federal Reserve Bank of Minneapolis, available online at http://www.minneapolisfed.org/publications_papers/pub_display.cfm?id=3333http://ww w.minneapolisfed.org/publications_papers/pub_display.cfm?id=3333

Miller, E. (2008) An Assessment of CES and Cobb-Douglas Production Functions, working paper 2008/5, Congressional Budget Office, available online at http://www.cbo.gov/sites/default/files/cbofiles/ftpdocs/94xx/doc9497/2008-05.pdfhttp:// www.cbo.gov/sites/default/files/cbofiles/ftpdocs/94xx/doc9497/2008-05.pdf

Mukerji, V. (1963) A Generalized SMAC Function with Constant Ratios of Elasticities of Substitution, The Review of Economic Studies, 30, 233-236

Pasinetti, L. (1962) Rate of Profit and Income Distribution in Relation to the Rate of Economic Growth, The Review of Economic Studies, 29, 4, 267-79 
Raurich, X., H. Sala and V. Sorolla (2012) Factor Shares, the Price Markup, and the (1964b) Elasticity of Substitution Between Capital and Labor, Journal of Macroeconomics, 34, 1, 181-198

Raval, D. (2011) Beyond Cobb-Douglas: Estimation of a CES Production Function with Factor Augmenting Technology, US Census Bureau Center for Economic Studies Paper No. CES-WP-11-05

Ricardo, D. (1817) Principles of Political Economy and Taxation, 1911 edition, London: John Murray

Samuelson, P. (1964a) Economics: An Introductory Analysis, 6th edition, New York:

McGraw-Hill

A Brief Survey of post-Keynesian Developments, in Lekachman, R. (ed.) Keynes' General Theory: Reports of Three Decades, London: MacMillan (1972) Collected Scientific Papers, Cambridge, Mass.: MIT Press

Solow R. (1955) The Production Function and the Theory of Capital, The Review of Economic Studies, 23, 2, 101-108

(1956) A Contribution to the Theory of Economic Growth, Quarterly Journal of Economics, 70, 1, 65-94

(1957) Technical Change and the Aggregate Production Function, Review of Economics and Statistics, 39, 3, 312-20

(1958) A Skeptical Note on the Constancy of Relative Shares, American Economic Review, 48, 4, 618-631

Shaikh, A. (1974) Laws of Production and Laws of Algebra: the Humbug Production Function, The Review of Economics and Statistics, 56, 1, 115-120

Volterra, V. (1931) Théorie Mathématique de Lutte pour la Vie, Paris: Jacques Gabay 